\title{
THE LEGALITY OF THE ANTI-MIGRANT ACTIONS OF THE ITALIAN AND OF THE HUNGARIAN GOVERNMENTS: IT IS MORE THAN JUST LAW. THE NECESSITY TO REFORM EXISTING RULES
}

\author{
Pietro Andrea Podda* \\ Harold Neal $^{* * *}$ \\ Veronika Zapalacova***
}

\begin{abstract}
This paper discusses the legal basis of those anti-migratory individual actions of certain states of the European Union, specifically Italy and Hungary, which have recently created a challenge to the enforcement of International and European Union legal rules on asylum. On the one side, legal rules are stemming from International Law, the case-law of the European Court of Human Rights, EU Law (i.e. Dublin Regulation) which impose specific duties on those countries where migrants and asylum-seekers first come. On the other side, there are countries (i.e. Italy, Hungary) that are or have been particularly exposed to the inflow of refugees and asylum-seekers. These countries, in these last years, have taken individual initiatives against what their Governments have perceived as a massive inflow of migrants. These initiatives have spurred a debate and have also contributed to EU initiatives and plans related to the reallocation of migrants.
\end{abstract}

This paper, after introducing the International and EU legal rules on the treatment of migrants and asylum-seekers, studies the legal basis for certain individual states' initiatives against massive migration, and the possible consequences of a conflict between the EU/International authorities and those states following restrictive pol-

\footnotetext{
Pietro Andrea Podda, Anglo American University, Prague, Czech Republic; pietro.podda @aauni.edu.

** Harold Neal, University of New York in Prague, Prague, Czech Republic; hneal@unyp.cz.

*** Veronika Zapalacova, Anglo American University, Prague, Czech Republic; veronika. zapalacova@aauni.edu.
} 
icies against migration. Finally, the paper suggests that the existing international and EU rules on asylum should be reviewed. This would also take into account the constraints that a massive inflow of migrants can create to individual states and would prevent conflicts between anti-migration national Governments and EU/International authorities.

KEYWORDS: Migration, Asylum, Non-refoulement, Dublin Convention

\section{INTRODUCTION}

Immigration is a constant phenomenon affecting European countries. In particular, the recent crisis and war in Northern Africa and the Middle East have created the presuppositions for massive flows of persons attempting at reaching the European Continent and settling there, eventually (but not necessarily) applying for asylum. These inflows of migrants have spurred a debate regarding the opportunities and constraints that huge arrivals create for those countries receiving them. ${ }^{1} 23456$. In particular, specific countries lie at the outer borders of the European Union and, according to the existing EU legislation (Dublin Regulation, see the next section), are primarily responsible for receiving migrating persons, identifying them, and examining their eventual asylum requests. The EU Law establishes that, in most of the cases, the state of the first arrival (basically those EU states with a border with Third Countries or with a sea border) is responsible for the process of offering support to migrants, selecting those with the right to obtain asylum or any form of protection and, eventually, to expel those without a title for staying.

\footnotetext{
Yilmaz, F.: Right-wing hegemony and immigration: How the populist far-right achieved hegemony through the immigration debate in Europe, Current Sociology, Vol. 60(3), 2012, [DOI:10.1177/0011392111426192], p. 368.

2 Davidov, E.; Meulemann, B.; Schwartz, S. H; Schmidt, P.: Individual values, cultural embeddedness, and anti-immigration sentiments: Explaining differences in the effect of values on attitudes toward immigration across Europe, Kölner Zeitschrift für Soziologie und Sozialpsychologie, suppl. Supplement, Vol. 66, Sep 2014, [DOI:10.1007/s11577-014-0274-5], pp. 263.

3 Koopmans, R.; Lancee, B.; and Schaeffer, M.: Social Cohesion and Immigration in Europe and North America: Mechanisms, Conditions, and Causality, Taylor \& Francis Group, 2014.

4 Dunn, G.: Destination Europe: The Persistence of Immigration to Europe, International Review, Vol. 36(3), 2015, pp. 15.

5 Ambrosini, M.: Irregular Immigration in Southern Europe: Actors, Dynamics and Governance, Springer International Publishing AG, 2018, pp. 51.

6 Etzioni, A.: Immigration: Europe's Normative Challenge, Journal of International Migration and Integration, Vol. 20(1), 2019, [DOI:10.1007/s12134-018-0593-x], pp. 67.
} 
The last years have witnessed a reaction from those states whose Governments have felt that their country was too exposed to the constraints created by the massive inflows of migrants and by the Dublin system. For example, both Denmark as well as Germany, during the peak of the inflow of migrants in 2015, had temporarily re-established controls at their borders with, respectively, Germany and Austria. The Hungarian Government has decided to build a wall to prevent the arrival of migrants going through Serbia and, at a certain point, has ordered the Army to patrol the border. ${ }^{79}{ }^{10}$ One further example is represented by the behavior of the Italian authorities during the period 2018-2019. The Italian Government of that time had repeatedly refused or delayed entry into the Italian ports to NGO boats carrying refugees allegedly rescued in the Mediterranean Sea. ${ }^{11} 121314$

This type of initiative has been at the origin of controversies and of continuous requests for a reform of the Dublin Regulation rules. The European Union has occasionally reacted to such requests. A decision was made in 2015 aiming at relocating 150,000 refugees from Iraq, Syria, and Afghanistan based on quotas (some countries, including Hungary, refuse to comply with their quota ${ }^{15}$. More-

7 Trauner, F.; Turton, J: Welcome culture: the emergence and transformation of a public debate on migration, Österreichische Zeitschrift für Politikwissenschaft, Iss. 1, 2017, [DOI:10.15203/ozp.1587.vol46iss], pp. 33.

8 Bocskor, A.: Anti-Immigration Discourses in Hungary during the 'Crisis' Year: The Orbán Government's 'National Consultation' Campaign of 2015. Sociology: the Journal of the British Sociological Association, Vol. 52(3), 2018, [DOI:10.1177/0038038518762081] pp. 551.

9 Guiraudon, V.: The 2015 refugee crisis was not a turning point: explaining policy inertia in EU border control. European Political Science, Vol. 17(1), 2018, [DOI:10.1057/s41304-0170123-x], pp. 151-160.

10 Carboni, G.: European Virtual Policies: capitalizing on immigration, Politeja, Iss. 63, 2019 [DOI:10.12797/Politeja.16.2019.63.10],pp. 153.

11 Evolvi, G.: Politics, Islamophobic Tweet. The Hashtags \#Brexit and \#chiudiamoiporti, Partecipazione e Conflitto, Vol. 12(3), 2019, [DOI:10.1285/i20356609v12i3p871] pp. 871.

12 Gontijo, L. C B; Lana, A. D. S.: Fear of the Other within the Contemporary 'Migration Crisis': Arab-Muslim Migration towards Europe and the Condition of Otherness Journal of Identity and Migration Studies, Vol. 14(2), 2020, pp. 91-111.

13 Iocco, G.; Lo Cascio, M.; Perrotta, D. Cl.: Sociologia Ruralis: 'Close the Ports to African Migrants and Asian Rice!': The Politics of Agriculture and Migration and the Rise of a 'New' Right-Wing Populism in Italy, Oxford Vol. 60 (4), 2020, [DOI:10.1111/soru.12304], pp. 732.

14 Berti, C.: Right-wing populism and the criminalization of sea-rescue NGOs: the 'SeaWatch 3' case in Italy, and Matteo Salvini's communication on Facebook, Media, Culture \& Society, Vol. 43(3), 2021, [DOI:10.1177/0163443720957564] pp. 532.

15 Podda, P. A. The Legality of Migrant Quotas and the Pronouncement of the Court of Justice of the European Union on Migrant Quotas after the Action for Annulment of Slovakia and Hungary. Does a EU Member State Have its Own Obligations to Respect EU Law and also the 
over, an informal mechanism of reallocation of migrants from Italy to some EU countries has been established.

In particular, the actions taken by the Hungarian Government of Viktor Orban in 2015 and those of the Italian Government in 2018-2019 have captured the attention of the media. The initiatives of the two Governments have generated a huge discussion with varying views regarding the political convenience, humanitarian perspective as well as technical legality of these initiatives. Our paper will concentrate on the latter and also on their political legitimacy, studying and discussing separately whether the decisions and actions taken by the Hungarian and Italian authorities have a legal basis.

We believe that an investigation into the legitimacy of these types of individual actions is worthy. So far, the literature has studied the problems related to migration and asylum mainly focusing on the difficulties experienced by migrants. The attention of researchers has been directed mostly to the hurdles, tragedies, and problems experienced by those persons fleeing their countries and Continents and coming into Europe. ${ }^{16} 1718192021$ This appears meritorious, in view of the legal as well as ethical/humanitarian connotations of the matter. On the other side, it is clear that a massive inflow of migrants may, in extreme cases, create serious hurdles to the receiving countries in terms of serious organizational and financial challenges as well as threats to public safety $^{22}$. This particular situation has generated an increase in anti-migratory

Right to Defend Public Order and Financial Stability?, Per Curiam, Journal of the School of Law of the Anglo American University, Prague, issue. 9, 2021, pp. 35.

16 Bhimji, F.: Contesting the Dublin Regulation: Refugees' and Migrants' Claims to Personhood and Rights in Germany. Intersections, Vol. 2(4), 2016 [DOI:10.17356/ieejsp.v2i4.214], pp. 5.

17 Gataullina, I. A.; Shmelev, D. V. ; Kozlova, O. ; Gilmutdinova, O. ; Shagbanova, I. B.; et al: The "New National Problem" in Europe: Problems of Migration Policy at the End of the 20th Century, European Research Studies, Vol. 20(4B), 2017, pp. 666.

18 Campbell, B.: Caradura: Migration, Informal Labor, and the Problem of Enacting Trust in a Spanish Enclave in Morocco, Political and Legal Anthropology Review, Vol. 41(1), 2018, [DOI:10.1111/plar.12246], pp. 160.

19 Papuc, P. C.: Parallel between the Refugee Concept according to the Convention relating to the Status of Refugees from 1951 and its Protocol from 1967 and the Refugee Concept according to European Law, Challenges of the Knowledge Society, 2018, pp. 583-592.

20 Hansen, Art (ed.): Involuntary Migration and Resettlement: The Problems and Responses of Dislocated People, Taylor \& Francis Group, 2019.

${ }^{21}$ La Rocca, G; Di Maria, R., and Frezza, G.: Media, Migrants and Human Rights. In the Evolution of the European Scenario of Refugees' and Asylum Seekers' Instances,

22 Trines. S. (2017). Lessons from Germany's Refugee Crisis: Integration. Costs. and Benefits. WENR. https://wenr.wes.org/2017/05/lessons-germanys-refugee-crisis-integration-costs-benefits. Accessed on the 1/3/2021 
feelings among Europeans leading to consequent actions aiming at preventing or acting against massive migration. Indeed, the literature has often relegated the analysis of the eventual legitimacy of actions like those of Italian and Hungarian authorities into a very secondary role. The dangers to public safety brought by massive migration have often been presented as "perceived," with little investigation into whether or not the perception is actually (un)grounded. The literature has so far not really expounded the legitimacy of actions (like those of the Hungarian and the Italian authorities) aiming at putting a limit to the number of migrants and asylum-seekers. ${ }^{23}{ }^{24}$ These actions are, eventually, often briskly dismissed as illegal or immoral, without a proper analysis of their legality and morality. ${ }^{25}$ This appears as a limitation because of the importance of these particular actions, in terms of their (il) legitimacy and also in view of their impact on the life of both migrants as well as the citizens of receiving states. Our paper aims at contributing to filling the gap.

This paper will be organized in the following way. The following section will present EU and International Law (including the case-law of the European Court of Human Rights) in the area of treatment of migrants and of refugees. The second section will provide details of the actions taken by, respectively, Hungary and Italy and comment critically on their consonance with those rules discussed in the previous section. The third section will expand the discussion in order to encompass also the consistency between these EU/International rules and some specific Principles of Law. Conclusion and references will follow.

\section{THE MAIN LEGAL RULES ON MIGRATION AND ASYLUM: INTERNATIONAL AND EU LAW}

This section will discuss the state of the art of legislation on Migration and Asylum. The first sub-section (1.1.) will review the main International Law rules and the case-law of the European Court of Human Rights on the duties of a state towards migrants and asylum-seekers, whereas the second (1.2.) will study the most relevant legal instruments of the EU Asylum and Migration Policy. Neither sub-section aims at offering a complete historical overview of the relevant legislation, nor the following pages are devised with the intention

\footnotetext{
23 Armstrong, A. B.: You Shall Not Pass! How the Dublin System Fueled Fortress Europe, Chicago Journal of International Law, Vol. 20(2), 2020, pp. 332.

24 Zapalacova, V. The capability of a Member State to protect its national security by placing a limit on mass irregular migration, Master Thesis, 2021, Anglo American University

25 Cervi, L.; Tejedor, S.: Framing “The Gypsy Problem”: Populist Electoral Use of Romaphobia in Italy (2014-2019), Social Sciences, Vol. 9(6), 2020, [DOI:10.3390/socsci9060105], p. 105.
} 
to summarize legal statutes. Nonetheless, the following pages will highlight those main legal principles applicable at the moment of the actions taken by the Hungarian and Italian Governments (these principles are still valid even at the moment of writing)

\subsection{MIGRATION, ASYLUM, AND INTERNATIONAL LAW}

International Law does not confer to any individual any right to migrate to a foreign state in order to enjoy better living standards. ${ }^{26}$ Hence, purely economic migrants do not have any right to enter any EU country, unless, of course, there is a specific country willing to accept them.

Nonetheless, international law recognizes the right of a person to object to the persecution of finding asylum in another country. The first relevant legislative instrument is Article 14 of the Universal Declaration of Human Rights which states that "Everyone has the right to seek and to enjoy in other countries asylum from persecution." Further documents are the United Nations Convention Relating to the Status of Refugees of 1951 (Geneva Convention) and the Protocol Relating to the Status of Refugees of 1967. An agency of the United Nations, the United Nations High Commissioner for Refugees (UNHCR) is in charge of monitoring compliance with the Convention.

The Convention of Geneva recognizes certain rights to persons who have a reasonable fear of being persecuted in their countries or the country of residence on the basis of race, religion, nationality, membership of a particular social group, or political opinion. All those states part of the Convention have the obligation to consider these persons as refugees and provide them with protection. In particular, the authorities of the states where the person seeking protection arrives must examine their demand, provide free access to Courts, provide accommodation and meals, provide administrative assistance, provide the possibility of assimilation and naturalization to refugees, cooperate with the UNHCR, and offer reception also to the family of the refugee. Those states where refugees arrive also have particular duties to refrain from, in particular, sending the refugee back to the country where they have fled from (principle of non-refoulement). Refugees have, for themselves and their families, the right to access education, medical assistance, the job market, and self-employment. On the other side, the refugee has to respect the law of the country offering him/ her protection. Refugees should not be penalized for having entered illegally the country where they apply for asylum. The Convention should not be of

26 de Voss, V.: The 2015 Refugee Crisis, Sister Namibia, Vol. 27(3), 2015, pp. 22 
benefit to persons having committed serious crimes or non-political crimes, in this type of case the principle of non-refoulement may not apply.

The Convention has been recently analyzed by scholars. ${ }^{27} 2829$ In our view, it maintains a certain balance between the duty imposed on states versus persons persecuted and the right for these states to protect their community against persons who, while eventually fulfilling the requirements for obtaining asylum, are considered as a danger to the security of a country or have committed particularly serious crimes according to a final judgment. As said, in these particular cases, the principle of non-refoulement does not apply. These particular provisions recognize the right of national authorities to avoid exposing their citizens to dangers even when the person representing a danger would otherwise be entitled to receive the status of refugee. Another provision (article 9) does not restrict a state "in time of war or other grave and exceptional circumstances, from taking provisional measures which it considers to be essential to the national security in the case of a particular person, pending a determination by the contracting state that that person is in fact a refugee and that the continuance of such measures is necessary in his case in the interests of national security." Nonetheless, the Convention does not specify whether or not a state is entitled to impose a limit to the number of refugees it can actually take or to the number of demands it can assess. Specifically, the Convention prohibits collective expulsions based on the nationality of the applicants

The problem with the acceptability of a limit to the number of arrivals/refugees acquires relevance when the arrivals exceed the financial and managerial capacity of a receiving state. The receiving state may not have sufficient resources in order to monitor the behavior of asylum-seekers, conduct investigations in case of reported crimes, guarantee fair trials, and the eventual execution of custodial sentences. These are reasons why certain states have expressed concerns in case of massive arrivals of migrants demanding asylum. ${ }^{30}$ These concerns are even stronger because it is perceived that a significant number of

27 Schultz, J.: The Internal Protection Alternative in Refugee Law: Treaty Basis and Scope of Application under the 1951 Convention Relating to the Status of Refugees 1967 Protocol, 2019

28 Papuc, P. C.: Parallel between the Refugee Concept according to the Convention relating to the Status of Refugees from 1951 and its Protocol from 1967 and the Refugee Concept according to European Law, Challenges of the Knowledge Society, 2018, pp. 583-592.

29 Üstün, E. Y.: The Internal Protection Alternative in Refugee Law: Treaty Basis and Scope of Application under the 1951 Convention Relating to the Status of Refugees and Its 1967 Protocol, Insight Turkey, Vol. 22(2), 2020, pp. 250.

30 Bove, V., Elia, L., \& Ferraresi, M. (2019). Immigration, fear, and public spending on security I VOX, CEPR Policy Portal. https://voxeu.org/article/immigration-fear-and-public-spending-security as accessed on the $1^{\text {st }}$ June 2021. 
asylum requests are purely instrumental and aim at guaranteeing the applicant with a temporary presence in Europe, eventually (and in extreme cases) as a cover for terroristic activities. ${ }^{31}$

A further legislative instrument invokable to prevent repatriation is the Convention on Human Rights and Fundamental Freedoms of the Council of Europe, in particular Article 3. ${ }^{32}$ Article 3 states that "No one shall be subjected to torture or to inhuman or degrading treatment or punishment." The case law is oriented towards giving priority to the migrant asylum seekers right to avoid the risk of ill-treatment than to the right of a state to deport a person deemed to be a threat to security, thus canceling the possibility to deport a refugee having committed a crime. In Application no. 19017/16), the European Court of Human Rights (ECHR) has established that even where national security is threatened, the receiving state of a person at risk of violation of his human rights cannot order deportation lacking a genuine adversarial procedure carried out before an independent judicial authority. In the case of Application no. 1365/07, the ECHR has blocked the expulsion of a suspected terrorist from Sweden, as he would risk, even at a reasonable speculative level, ill-treatment in his country based on the reason for his expulsion from Sweden. ${ }^{33}$ A similar orientation is expressed also in Applications No. 8139/09, 25803/94.

The ECHR has clearly established a principle, according to which those states part of the Convention should follow a proper judicial procedure before establishing that any person represents a danger to public security. Moreover, these states (for example Art. 3 of the Convention) are in any case not allowed to deport this person back to a country where he/she risks "inhuman or degrading treatment or punishment." This doctrine is certainly an expression of a noble idea, avoiding that any human being risks ill-treatment. On the other side, the law of the Convention and the doctrine of the ECHR may also create the presuppositions for serious constraints when states receive large amounts of migrants. There is a significant number of obligations posed on receiving

31 Jones W. , Teteytelboym, A, and Rohac, D. .. Europe's Refugee Crisis: PRESSURE POINTS AND SOLUTIONS, American Enterprise Institute, 2007, https://www.aei.org/research-products/report/europes-refugee-crisis-pressure-points-and-solutions/ as accessed on the $25^{\text {th }} \mathrm{Sep}$ tember 2021

32 Webster, E.: Dignity, Degrading Treatment and Torture in Human Rights Law: The Ends of Article 3 of the European Convention on Human Rights, New York, 2018, Routledge.

33 "Even in the most difficult circumstances, such as the fight against terrorism and organised crime, the Convention prohibits in absolute terms torture and inhuman or degrading treatment or punishment. Unlike most of the substantive clauses of the Convention and of Protocols Nos. 1 and 4, Article 3 makes no provision for exceptions and no derogation from it is permissible under Article $15 \S 2$ even in the event of a public emergency threatening the life of the nation." (https://rm.coe.int/1680665ae0) accessed on the 1st July 2021. 
states, which are expected to offer accommodation, legal and administrative assistance to any person (and their family) demanding asylum on the basis of the Convention. Moreover, receiving states are expected to examine the demand and reconstruct the story of the applicant. In presence of massive inflows, a state needs to invest a significant amount of financial and managerial resources in order to comply with these obligations. Guaranteeing access to accommodation, access to education, free legal administrative assistance are costly activities. The receiving state is certainly allowed to place a migrant in detention if there is a need. Nonetheless, this also entails costs and practical difficulties, in view of the need to provide legal assistance, translation, and appropriate space in correctional facilities. Moreover, reconstructing the story of a person (who may come without a passport and a clear identity) in order to verify the effective risks of ill-treatment may become very difficult. The picture becomes even more complicated because receiving states are not allowed to deport a person who is considered to be a danger for security in case the person risks ill-treatment in his home country. The practical consequence is that, according to the ECHR case law, receiving states may (at least theoretically) be put under serious pressure and may even be requested to tolerate the presence of persons considered to be a danger for their community. The ECHR acknowledges these constraints; however, it still states that the protection of the migrant against probable ill-treatment takes priority. Because of this fact, (even if the Geneva Convention does not protect convicted criminals against deportation) we maintain that the current international legislation on the protection of persons at risk of persecution is migrant centered.

\subsection{THE EU ASYLUM AND MIGRATION POLICY}

The European Union has, over the time, developed specific legal rules on the matters of Migration and Asylum, following the evolution of International Conventions and the law and case law of the Council of Europe. The EU has created the Common European Asylum System (CEAS) and has created some uniform standards, even if the member states retain a certain space of autonomy. The various rules aim at 1) guaranteeing asylum and protection to persons needing it according to those legal instruments reviewed in the previous section and 2) establishing criteria for the identification of the state responsible for reception, examination of eventual demand of protection, and eventual expulsion of persons not fulfilling the criteria at point one above. 
An important piece of EU legislation on migration is the Dublin Regulation. 34353637 The Dublin Regulation, in its last version from 2013, represents the most important legal instrument on the criteria for the identification of the EU member state responsible for the reception, examination of the demand of protection, and eventual expulsion of a Migrant. This latter point is of major relevance because the actions of those Governments we are studying are presented by their proponents as a reaction against the inefficiency and unfairness of the Dublin Regulation's mechanisms. One of the most important criteria for the identification of the responsible state is the one indicating that this responsible entity is the First State the migrant has arrived at. Technically, this is a residual criterion, applicable when the person arriving in the EU territory does not, for example, have family members in or a visa issued by a member state different from the one where the migrant him/herself has first entered the EU territory. Nevertheless, the criterion of the "First Country" is the one most applied in practice and is the target of the reaction of those states (like Hungary and Italy) that lie at the external border of the EU (including maritime borders) and are logically (among) the responsible state in many cases. Based on the Dublin Regulation, the responsible state is legally required to respect the principle of non-refoulement, inform the migrant (in a language known or supposed to be known by this latter) of their right to present a demand for protection, offer accommodation, examine the eventual demand request and guarantee a procedure of appeal in case of rejection of the request. Clearly, responsible states may face difficulties in respecting these rules when the number of arriving persons exceeds certain limits. This even if a special mechanism, called European Asylum Support Office (EASO), has been devised in order to offer assistance to the responsible states in case of disproportionate inflows.

The principle of the First Country is under discussion since the emergence of the refugee crisis of 2015. Indeed, a massive inflow of migrants may impose a heavy financial and organizational burden on the state receiving large numbers of persons. For this reason, the European Commission has announced a plan to shift towards a system of quotas, in order to redistribute the migrants across

34 Armstrong, A. B.: You Shall Not Pass! How the Dublin System Fueled Fortress Europe, Chicago Journal of International Law, Vol. 20(2), 2020, pp. 332.

35 Bhimji, F.: Contesting the Dublin Regulation: Refugees' and Migrants' Claims to Personhood and Rights in Germany. Intersections, Vol. 2(4), 2016 [DOI:10.17356/ieejsp.v2i4.214].

36 Bugge, M.: Obedience and Dehumanization: Placing the Dublin Regulation within a Historical Context, Journal of Human Rights and Social Work, Vol. 4(1), 2019), [DOI:10.1007/ s41134-019-0090-y], pp. 91-100.

37 Cafiero, C.: The Dublin III Regulation: critiques and Latest Attempts to Reform, Union of Jurists of Romania. Law Review, Vol. IX(1), 2019. 
EU states based on the criteria like the population and the GDP of the EU member states. The underpinning idea is that it would be fair to release those EU member states located at the external borders of the EU of those undeniable hurdles related to the practical difficulties described above. Moreover, the picture becomes even more problematic taking into account the prohibition to deport anybody, including a criminal, to a country where he risks ill-treatment (a considerable number of home countries of refugees). However, at the moment of writing, these initiatives have not been transformed into a reform of the Dublin Regulation and the principle of the First Country still fully retains its legal validity. An eventual reform would request the approval of the majority of states, which is far from being realistic at the moment. At the moment, the redistribution of migrants is happening on the basis of informal and voluntary mechanisms of solidarity.

The current legal rules may seem to be the origin of a situation of unfairness, where specific countries (Spain, Greece, Italy, Malta, Croatia, and Hungary) are automatically exposed to (and the subsequent concrete risks of) major constraints only on the basis of their geographical location. In particular, a country such as Malta is in practice not able to comply with the Dublin obligations given its limited size and because of the exiguity of its population. Nevertheless, the state of the art of the legal rules is such that these countries are legally required to offer assistance to migrants irrespective of the hurdles that this may create on their financial balance and of the risks for the security of their citizens. A reform of the Dublin rules with a redistribution of migrants may eventually become an expression of solidarity across the EU. Nevertheless, those states not at the frontline (these are the majority of EU states, whose votes would be necessary to change the system) have actually an interest in retaining the status quo. The various National Governments hesitate to share the financial and organizational burdens of receiving migrants also in order to avoid difficulties at the moment of re-election.

\section{THE LEGALITY OF THE REACTION OF INDIVIDUAL STATES: THE CASES OF HUNGARY AND ITALY}

This section will discuss the legality of two types of behaviors followed by two specific countries members of the European Union: Hungary and Italy. Their national Governments have, rightfully or wrongly, decided that the inflow of migrants has become disproportionate, financially and organizationally unmanageable, and dangerous for the security of their citizens. The first subsection (2.1.) will study the Hungarian case, the second (2.2.) will focus on the Italian case. The current literature tends to describe Orban and Salvini in quite 
negative terms, presenting them as illiberal and populistic 383940 . Nonetheless, there is more room for a critical discussion of the legality of their measures. This section attempts at doing so.

\subsection{THE HUNGARIAN CASE}

During the second half of 2015, the Government of Hungary led by Prime Minister Orban has shifted towards an anti-migrant policy. This policy has a precise ideological underpinning, namely the overt refusal of those legal and political traditions according to which there cannot be a limit to the duty to offer reception and examination of requests for protection. The Hungarian authorities, despite the pressure put on them by various EU bodies, other member states, and NGOs, have decided to block or seriously limit the arrival of migrants from neighboring countries. The latter are mostly persons coming from Africa or the Middle East.

The legality of the Hungarian Government's actions can be studied by deconstructing their various manifestations. The simple construction of a fence at the border with Serbia (which is an external EU border) is, in itself, a perfectly legal act, as a sovereign state has the full right to protect its external border. Actually, paradoxically, Hungary has a major responsibility towards the whole Schengen area, as the Hungarian border is also the border of the Schengen area. There is no rule of International or EU Law technically and explicitly preventing a sovereign state from building any fence within its own territory. Hence, insofar as the construction of the fence is discussed per se, Hungary is not infringing any legal commitment, leaving aside all political and symbolic aspects.

Indeed, the construction of a fence with Serbia may eventually turn out to be legally questionable in case it results in a de facto refoulement of asylum-seekers. The Hungarian border patrols have been instructed to oppose physical resistance against the attempts of groups of migrants to enter the country. This fact is still not a representation of illegality in itself, in view of the right of any authority of a sovereign state to refuse and enforce refusal of entry to foreigners not entitled to stay in the country. Nonetheless, some of these foreigners

38 Anastasìa, S.; Anselmi, M.: Populist Punitiveness in the Italian Populistic Yellow-Green Government, Partecipazione e Conflitto. Vol. 13(3), (2020), [DOI:10.1285/i20356609v13i3 p1469], pp. 1469.

39 Körösényi, A.; Illés, G., and Gyulai, A. G.: The Orbán Regime: Plebiscitary Leader Democracy in the Making, Taylor \&amp; Francis Group, 2020.

40 Castaldo, A.; Verzichelli, L.: Technocratic Populism in Italy after Berlusconi: The Trendsetter and his Disciples, Politics and Governance, Vol. 8 (4), 2020, [DOI:10.17645/pag. v8i4.3348], pp. 485. 
may be entitled to receive international protection, based on those rules discussed in the first section of this paper. This fact may pose a legal problem. Hungary should not expose these persons to the risk of suffering inhumane treatment, on the basis of the Geneva Convention. Those migrants whose entry to Hungary was denied by the local authorities were already in Serbian territory, after having crossed its territory and previously the Greek territory. Therefore, the refusal of entry from the Hungarian authorities would be justified in case those countries crossed by the migrants (in particular, Serbia considering that the migrants were already in Serbian territory when trying to enter Hungary) were already able to offer sufficient standards of international protection to the migrants (Safe country). Unfortunately, at the time the action of building the fence was taken, there was not an official EU list of safe (and by exclusion unsafe) countries. Therefore, one cannot automatically conclude that Hungary has been violating the principle of non-refoulement when it had basically not allowed those migrants already in Serbian territory entry into Hungary. Serbia is a full UN Member, therefore bound to respect all duties from the UN Charter and is also a member of the Council of Europe and a signatory of the Geneva Convention. Moreover, it is run by a regularly elected Government and is not in a state of war. Because of these points, the Hungarian authorities are not automatically accusable of violating the principle of non-refoulement when they refuse entry into their country to migrants already in Serbian territory. The effectiveness of Democracy and the fair treatment of refugees in Serbia is criticized by some NGOs. ${ }^{41}$ Nonetheless, these NGOs are private organizations and are not entitled to prepare themselves a list of Safe/Unsafe Countries that can have a binding effect on a Sovereign Country like Hungary is. On the other side, the UNHCR argues that rejections to supposedly safe countries are also legally problematic since the fact that a specific individual might be at risk on a personal basis.

In view of the discussion presented in the paper, it appears that irrespective of any political views, the action of building a fence is not in itself illegal. However, the action of blocking the entry of migrants coming from the Serbian territory is legally questionable.

\subsection{THE ITALIAN CASE}

The governmental authorities of Italy have delayed or blocked the entry of private boats carrying migrants allegedly rescued by these private boats while the

41 [http://www.bgcentar.org.rs/bgcentar/eng-lat/wp-content/uploads/2021/03/Human-Rightsin-Serbia-2020-za-web.pdf] accessed on 1/7/2021 
migrants themselves were attempting to cross the Mediterranean Sea. These actions have been taken several times during the period 2018-2019 before a reshuffling in the Governmental coalition has occurred. These initiatives are inspired by underpinning ideas, according to which the number of migrants coming to Italy has become disproportionate, the state cannot manage the procedures of reception, examination of requests, and eventual expulsion and the massive inflow of migrants entails concrete risks for the security and welfare of citizens because of terrorism and other types of crimes.

The Italian authorities, at the time of the facts, were led by a triumvirate composed of Giuseppe Conte (Prime Minister) and Luigi Di Maio and Matteo Salvini (both of them Deputy Prime Ministers, even if Salvini has directly been giving the orders to refuse entry to the boats. The Italian authorities have invoked the following legal grounds in order to justify the refusal of allowing entry to the NGO boats:

1) Italy was not the closest safe harbor at the moment when the migrants have been rescued. The boats have purposefully avoided directing towards countries like Tunisia, Algeria, Malta, or Libya itself

2) The authorities of Malta have intentionally avoided answering the requests for assistance even when the rescuing boat were crossing their own waters

3) Italy is not the state responsible in view of the Dublin Regulation when the boats are registered in any other EU Member state than Italy. According to the Italian authorities, the boats themselves would represent an extension of that member state's territory abroad. Hence, for example, in the case the boat carrying the migrants has been registered in the Netherlands, then this latter would be the responsible state.

The points highlighted above as going to be discussed separately. We discuss the arguments themselves, not the veracity of the concrete facts alleged by the Italian authorities at points 1) and 2). As for point 1), a definition of the meaning of the concept of "Safe Harbor" would be helpful. According to a certain interpretation, a Safe Harbor is a place offering repair from adverse weather and attacks. ${ }^{42}$ According to this interpretation, any place closer to Italy at the moment when the migrants were rescued and able to offer protection against adverse weather and attack would represent a Safe Harbor. Nevertheless, it is clear that boats could hardly return migrants to Libya, where there is a war in the act. Still, the boats' authorities should direct to other countries than Libya when they are closer than Italy is. Nonetheless, there is a further point to consider. At the moment when the Italian authorities were denying the boats' entry

42 [https://www.collinsdictionary.com/dictionary/english/safe-harbour], accessed on 1/7/2021 
into the Italian harbors, the boats were actually closer to Italian land. This means that at that moment, the Italian harbors were the closest Safe Harbor. Forcing the boat away could expose the migrants to risks, in case the condition of the boat itself, or the health of the passengers and the meteorological conditions are adverse. Overall, considering all points, it seems that the denial of entry or delaying of entry into Italian harbors is legally problematic. The boats have regularly been provided with food and medicaments, passengers in critical health conditions have immediately been allowed to access the Italian land territory. However, the permission to stay in front of the land and the supply of food and medicaments is hardly equivalent to the provision of a "Safe Port". The Italian authorities argue that 1) some rescuing boats have purposefully been directed towards Italy even when another closer Harbor was available or 2) in some cases the authorities of Malta and Tunisia have (unlawfully) denied entry and repair to the rescuing boats. However, while it is clear that these alleged particular behaviors may entail legal responsibilities for the authors, this does not seem to give the Italian authorities the right to deny repair to the boats and their passengers. Eventually, the Italian authorities could take action against those other national authorities having refused entry and/or against those persons who have eventually purposefully directed their boat to Italy even when a closer Safe Harbor was available.

We turn now to the second point, namely the discussion on Italy not being the state Responsible in case the rescuing boats are registered in another EU state. It all depends on whether or not a boat is a part of the territory of the state where it has been registered. This is a complex issue, whose solution goes beyond the scope of this paper. Nevertheless, the denial of access to a Safe Harbor is hardly justifiable on the basis of the argument according to which Italy is not the responsible state in terms of the Dublin Convention whenever the rescuing boat carries the flag of another EU state. Italy would still be obliged to offer a Safe Haven and eventually the other particular EU state would have to accept to take the migrants over and treat their case. Any eventual refusal from any specific state could in itself be a reason for an action of the Italian or (EU) authorities. Italian prosecutors could eventually act against the carrier of the migrants, allegedly because of solicitation of illegal immigration. However, this is a different issue, distinguished from the obligation of giving immediate shelter (Safe Haven) to those persons in immediate danger.

\subsection{DISCUSSING THE CASE STUDIES}

The section on the case studies mentioned above has shown that the legality of those actions taken by the Hungarian and Italian authorities may, at least in the case of Italy, be questioned in formal terms. Nonetheless, there are sever- 
al remarks regarding the compatibility of the current international legislation with some legal principles like Public Security and Order, Proportionality, and Reasonableness of legal obligations. The main problem is that these various principles, while recognized, are sometimes hard to invoke in practice.

As highlighted in the first section of this paper, the current international rules tend to be migrant-centered. The whole set of legal standards is inspired by an underlying aim. The main aim is that migrants are offered all possible guarantees that their eventual request of protection is examined, their personal story is reconstructed, they are offered adequate information and legal assistance, and that an eventual rejection of their demand may be appealed. According to the UNHCR, also the designation of a "Safe Country of Origin" should be avoided because it would undermine the rights of those individual persons who, while coming from a technically Safe Country, are objects of individual persecution. Hence, according to this view, the automatic rejection of persons going through Serbia could represent an infringement of the Geneva Convention. This would lead, in practice, to an (ab absurdum) conclusion: that no application should be rejected or go through a summary treatment not even when the applicant comes originally from or has been crossing through a supposedly Safe Country.

Our point here is that the migrant-centered perspectives of the Geneva Convention and the UNHCR are themselves questionable. The Geneva Convention's perspective implicitly assumes that those states receiving the migrants have sufficient financial and managerial resources in order to offer reception, accommodation, legal assistance in a language that the migrants know or are supposed to know. The case law of the ECHR puts the safety of the refugee in any case ahead of the constraints that illegal and criminal behaviors from their side may create to receiving communities. All these rules are problematic because of various reasons. At first, states may encounter serious financial and managerial burdens when offering accommodation, means of subsistence to refugees, and, eventually, even free legal assistance/translation and sometimes even space in correctional facilities in case of conviction. A massive inflow of migrants and/or specific migrants may represent a concrete risk for the financial stability, welfare, and security of the citizens of those countries receiving significant amounts of foreigners who are often not familiar with the recipient's culture, language, and hardly employable in remunerative working activities. These persons may logically tend to recur to crime, even petty crimes, with a certain frequency, leaving aside also the terrorism-related risk. Irrespective of crime, sudden massive inflows of migrants may "aggravate long-standing structural problems and bottlenecks in local infrastructures, such as housing, transportation, and education..... Similarly, although this is not usually the case, in some circumstances, large numbers of low-skilled migrants arriving 
in a particular area may have a negative impact on the local labor market prospects of low-skilled residents already present." ${ }^{43}$ These various arguments are not really ignored by the EU authorities themselves, as they represent part of the underlying rationale for the Decision EU/2015/1601 on the relocation of certain migrants (see below). Nonetheless, the main perspective of the EU and International Law is, as said, migrant-centric.

We identify that the migrant-centered perspective is a possible limitation of the Geneva Convention and, even more, of the case-law of the ECHR. In our view, these legal sources may, at least in extreme cases, fail to find a balance between the legitimate need of offering protection to persons in need and the objective difficulties and limitations that any country may encounter when the inflows exceed the capacity to offer reception and comply with those other consequent obligations.

The points raised above acquire more relevance if one considers that the experience has shown that the current international legislation leaves the room open to abuses. Besides genuine asylum-seekers, there is also a certain number of persons who are actually economic migrants, moving away from their country to Europe not in order to escape persecution but in order to find better living standards. These persons are not protected by the Geneva Convention but still, the attempt at present requests of protection claiming to be political refugees or persons deserving humanitarian protection.

These limitations in international law and case law may also take legal relevance. states are entrusted with the task of guaranteeing order, stability, and security to their citizens (see also article 12 of the International Convention on Political and Civil Rights). ${ }^{44}$ Hence, a challenge arises. What would happen should a state be able to demonstrate that a massive inflow of migrants really creates a hardly manageable financial burden and a risk for the security of its citizens? In such a particular type of case, presented here as hypothetical, the national authority may have a ground in declaring that the migrant-centered connotation of those international provisions imposes a disproportionate burden on the very recipient state. This burden could in principle go beyond the

\footnotetext{
43 Scarpetta, S. How OECD countries can address the migration backlash, OECD Paper Serie, https://core.ac.uk/download/pdf/80784892.pdf, ccessed on the $1^{\text {st }}$ June 2021.

44 Article $12-1$. Everyone lawfully within the territory of a State shall, within that territory, have the right to liberty of movement and freedom to choose his residence. 2. Everyone shall be free to leave any country, including his own. 3. The above-mentioned rights shall not be subject to any restrictions except those which are provided by law, are necessary to protect national security, public order (ordre public), public health or morals or the rights and freedoms of others, and are consistent with the other rights recognized in the present Covenant. 4 . No one shall be arbitrarily deprived of the right to enter his own country.
} 
capacity of the state to comply with the international obligations and, at the same time, guarantee its duty of promoting the welfare and the security of its own citizens. Obviously, any national authority issuing this type of declaration (and acting on its basis) would have the onus of proving that the inflow of migrants is really disproportionate and prone to create real and hardly manageable dangers for its citizens. Indeed, should this be proved, then the national authority could eventually have a legal basis for arguing that those international provisions which basically create unconditional burdens for the state of arrival, irrespectively of the state's reasonable capacity to manage the arrivals and guarantee security to its citizens, are themselves legally questionable. These types of arguments could find a greater audience should a national authority become able to demonstrate that a significant number of migrants is actually attempting to abuse the legal provisions and stay in Europe as long as possible without filling the requirements for asylum. These problems may acquire a certain relevance since some countries (see below) may actually reasonably end up demonstrating that their actual capacity to face the duties of a responsible state is limited. Reception and accommodation can be costly, convenient spaces are not necessarily easy to find, there is only a limited number of legal experts, translators, professionals qualified to investigate and eventually incriminate/defend and there is, in case, even a limited amount of rooms in correctional facilities. Inflows of huge numbers of migrants may in principle really force some states to deploy considerable resources, eventually with great efforts. The risks for security cannot be denied considering that, based on common sense, it can be expected that persons without financial resources and liable to pay debts to migrant smugglers can easily turn to commit crimes.

The arguments discussed above may in principle find legal recognition, even if this would not be easy, mostly because concepts like "public security" and "public order" are themselves ill-defined. The balance would be hard to strike. The very case law of the ECHR indeed prevents signatories' states from escaping their obligation alleging reasons of public order and security. Nonetheless, the competence of any national state on deciding on national security, while vaguely defined, is well embedded in the Treaty on the Functioning of the European Union (Art.72, see below for a deeper discussion) and some national judicial authorities may even consider it also as part of the constitutional order of the state. A given competent national authority (i.e. a Constitutional Court) may even state on the technical incapacity of a state to surrender its duty to guarantee public order and security. This could, in principle, create a serious conflict between international and supreme national authorities. Leaving aside the possibility that any state or a group of states might withdraw from the Geneva Convention (according to the Convention itself) and, in extreme cases, 
even from the Convention of the Council of Europe. So far, we are talking at a speculative level, but we cannot exclude concrete actions either.

We would bring more material to discuss the very questionability of the existing International and EU rules discussed in the first section of this work. Some countries may reasonably end up demonstrating that their actual capacity to face the duties incumbent on a responsible state is limited. The most remarkable example is Malta. Malta is a small country with only half a million residents and lies at the external border of the European Union. Malta, reasonably, cannot be expected to be capable of meeting those legal requirements as a responsible state. Indeed, Malta is located in an area crossed by many boats carrying migrants and, in many cases, is likely to be classifiable as the responsible state for 1) offering a Safe Harbor and 2) treating migrants' asylum requests. In view of the numbers of migrants crossing the Mediterranean Sea, it appears as self-understanding that this small country cannot offer reception, accommodation, legal assistance to all those who may actually turn up asking for it. The Maltese authorities cannot be expected to monitor the behavior of all migrants/refugees and eventually follow those legal procedures necessary to investigate, incriminate and sanction migrants in case of necessity. Nonetheless, Malta is still legally compelled to offer assistance to all migrants entering its territory, including its territorial waters, offering Safe Harbour in case of need. We conclude that the country is theoretically exposed to meet obligations that it is not capable of meeting.

A given state facing unreasonable burdens, like Malta in our example, may object that legal rules cannot impose unrealistic and unreasonable obligations. This is a Principle of Law discussed already by Fuller. ${ }^{45}$ Fuller mentions the actual possibility of compliance as being one of the essential characteristics of legal rules. In addition, legal rules should respect the principle of proportionality. Legal rules violate the principle of proportionality when, in order to achieve a certain aim, they end up imposing disproportionate burdens on their addressees. This principle, and the one of Fuller, could be useful to explain those alleged (from the Italian authorities) refusals from the Maltese authorities of complying with their international obligations. To release Malta of a serious burden, other EU countries have spontaneously been taking charge of the bulk of those persons for whom Malta should be the responsible state. Nevertheless, this solution has not been formalized. In case of a major emergency, Malta would probably put a limit to entries thus infringing those laws studied in the previous section. However, Malta could eventually invoke the unreasonableness and disproportionality of the burden as a legal justification

45 Fuller, L.L.: The Morality of Law, rev. edn., Yale University Press, 1969. 
for its behavior. In practice, this has allegedly already been done by the Maltese authorities exactly because of the limited capacity of Malta to receive migrants (and the other EU member states, in particular Italy, a de facto taking the migrants for which Malta should be responsible). Nonetheless, the solidity of the argument has not been tested in Court.

As for Proportionality, the propensity of a Court to declare that specific EU rules violate the principle of proportionality has been tested on various occasions. ${ }^{46}$ We identify two cases providing indication regarding the attitude of the Court to excuse the violation of disproportionate rules. The first is case 231/83, where the French Government had set a minimum resale price, thus canceling the competitive advantage of imported oil, infringing the rules on the Freedom of Circulation of Goods. The French authorities, among other arguments, claimed also that an eventual removal of the minimum price would have probably originated riots and hardly manageable violent actions from the side of privately organized groups, thus threatening public security. The Court of Justice replied that the justification presented by the French authorities could not be accepted, as the French authorities themselves had not been able to demonstrate that the riots and demonstrations would have been unmanageable. Another case, more recent and directly related to migration, is case C643/15. Here the Governments of Hungary and Slovakia had requested the annulment of the obligatory reallocation ${ }^{47}$ of 150,000 migrants within the EU based on quotas. The two-member states have claimed, among other arguments, that the related obligations would cause disproportionate burdens. The Court of Justice has replied that there was no evidence of any eventual lack of proportionality of the Decision, considering the urgency, una tantum connotation of the decision, and the ambiguity of the numbers. The two cases discussed in this paragraph show that the Court has rejected the existence of a threat to public security and a disproportionate burden in the specific cases, but has not dismissed the validity of the argument per se. This leaves an important question open: what would the Court of Justice decide should a member state be able to demonstrate that the massive inflows of migrants really create a disproportionate financial and organizational burden and a real threat to public security? Could the member state involved successfully invoke the Article 72 TFEU? ${ }^{48}$ The EU case law

\footnotetext{
46 Horspool, M. and Humphreys, M: European Union law, Oxford, Oxford University Press, 2018.

47 Council Decision (EU) 2015/1601 of 22 September 2015 establishing provisional measures in the area of international protection for the benefit of Italy and Greece.

48 The Article stats that: this Title shall not affect the exercise of the responsibilities incumbent upon Member States with regard to the maintenance of law and order and the safeguarding of internal security.
} 
does not offer a final answer, not even after its most recent decision. ${ }^{49}$ There is a grey area and the Court has manifested a certain openness to consider also a potential threat to public order as a factor relevant to state's decisions. The Court has shown a certain reluctance towards accepting such an argument in concrete, but it has not ruled its potential validity out.

Besides the Court of Justice, also as said, some National Constitutional courts could question the conformity between 1) unconditional and migrant-centered obligations of International and EU Law and 2) national constitutional provision. An eventual pronouncement could break important international equilibria.

The analysis of the last paragraphs re-open the question about the legality of the actions of the Hungarian and the Italian authorities. Obviously, these authorities would bear the onus of proving that those constraints they have claimed having been exposed have really been disproportionate and not manageable in practice. Nonetheless, should they succeed in this task and we, then they could invoke defects in those very international and EU Laws they were expected to respect and, eventually, try to rely on the Article 72 TFEU. It is important to remind that the Court has been strict as for the scrutiny of the actual danger to public order and of the violation of proportionality. Nonetheless, the avenue has not been closed.

Besides purely legal arguments, there would also be another important direction worthy of consideration. EU and International authorities have an imperfect capacity to enforce decisions that national authorities really refuse to obey for political reasons. This migrant-centrism is politically very unpopular and it is attacked by various political parties interested in maximizing their consensus. A significant part of the electorate has developed, rightfully or wrongfully, the perception that massive migration generates too many problems and that existing international standards should be reviewed. On this basis, some national authorities, as in the case of Orban and of the Italian Government, have recurred to extreme forms of preventing/limiting migration, as studied in the previous section. The analysis of the current section has shown that the legality of these actions is, at least in the case of Italy, questionable. Nevertheless (and irrespective of the possibility that the actions of these Governments may finally actually result to be legally valid), there is objectively little that the judicial international authorities can do in order to force these Governments into changing their path of action. This is because 1) the European Union does not dispose of real coercive means to enforce the pronouncements of the Court of Justice and 2) the pressure of NGOs and other Organizations has not resulted

49 [https://europeanlawblog.eu/2020/04/14/coming-to-terms-with-the-refugee-relocation-mechanism/], accessed on the 1/7/2021. 
to be effective. Despite all pressure from these various entities, neither Orban nor the Italian Government on duty at the time of the denials has changed their path of action (the successive reshuffling in the Italian Government Coalitions is, officially the result of internal dissents among the coalition, not an imposition from other authorities). This evidence indicates that some Governments may actually willfully elude their legal international obligation without any EU/International authorities being, in practice, able to coerce these very national Governments. These latter representatives are likely to benefit from an increase in popularity due to the firmness demonstrated towards excessive migration and, consequently, are likely to persist with their action. The combined effect may be a chaotic situation, meaning migrants are blocked at the terrestrial or maritime border of the EU.

The solution appears difficult also in view of the fact that both supporters, as well as opponents of the national anti/migratory policies, present ethically valid arguments. On the one side, the former claim that the rejection of persons likely needing help against war and persecution is unethical and illegal. On the other side, the latter highlight that their countries cannot take responsibility for numbers like those seen in the last years without seriously compromising the reasonable management of resources and the safety of citizens (even against violent and petty crimes). There is a general agreement regarding the necessity to reform the Dublin Regulation, however, there are no concrete actions taken. Moreover, the EU could/should take coordinate actions in order to pressure those countries from where migrants come from into 1) effectively controlling their maritime coasts in order to prevent massive departures and 2) take concretely migrants back when asylum and protection have been denied in the EU and 3) the EU should take or authorize reasonable and proportionate initiatives aiming at guaranteeing the safety (including safety against violent and petty crimes) of EU citizens in case of massive arrivals. The European Union has demonstrated certain inertia under all lines, despite talks and proposals. This appears extremely unfortunate as EU border states have now taken individual actions which, legally or illegally as they might be, are de facto suspending the effectiveness of those international rules on Asylum and Protection. Should the EU concretely take actions like those described at points 1- 3 above, then those member states would have less ground for arguing that they are forced to take individual initiatives questionable in terms of International and EU Law.

It appears that some further necessary steps should be taken in order to update the existing international provisions. The example of Malta reminds us that no state has infinite resources for guaranteeing reception, accommodation, and examination of demands for protection and, at the same time, also guaranteeing the safety of its citizens and public order in case of massive arrivals. This is 
a crucial point: the difficulties that massive inflows of migrants can in principle create to receiving states should not be denied nor ignored or undermined by any international body. We are not stating here whether or not the Hungarian and Italian authorities are facing disproportionate difficulties. We just propose that this type of possibility should be seriously considered by international and EU rules and appropriate instruments should be devised. Otherwise, as said already, some states could, rightfully or wrongly, 1) conclude that the migratory pressure put on them is unreasonable and represents a threat to the security of their citizens 2) take actions aiming at blocking or reducing the inflows, eventually also going against their formal obligations. This is happening already, as the Hungarian and the Italian cases have shown, and it can certainly jeopardize the credibility and effectiveness of those international provisions aiming at protecting persons really deserving protection and asylum.

Overall, it seems that there is a need of reforming the existing rules, which have been devised having the migrant and his/her needs as the center of the whole system. Certainly, it makes sense to respect those persons who may have imperative reasons, eventually the risk of saving their lives, for leaving their home countries and applying for asylum in the EU. On the other side, the experience of the last decade has demonstrated that receiving states can have also a limited capacity to guarantee the respect of the rights of a massive number of migrants and, at the same time, guarantee also their social stability, public order and the safety of their citizens. The international and EU rules should take both sides of the problem into due and proportionate consideration.

\section{CONCLUSION}

This paper has analyzed the legality of the individual actions taken by the Italian and the Hungarian authorities and has established that, while finding a clear-cut threshold of legality/illegality is questionable, elements are suggesting that at least the Italian Government has violated the existing international and EU rules. Nonetheless, also these rules may in themselves be legally problematic when they end up imposing unconditional burdens on those responsible states. This may result in disproportionate constraints and a threat to public order and the safety (including against violent and petty crime) of their citizens. Moving from this argument, some countries have decided that the pressure had become unmanageable and have decided to take individual actions in order to deter or limit the inflow. Our paper suggests also that, apart from political pressure, there are few instruments that the international and EU authorities may use in practice in order to coerce recalcitrant states into respecting relevant international obligations. Moreover, their national Governments, when implementing anti-migratory policies, often enjoy certain support 
from their constituents. This support may be a factor able to reinforce the firmness of those national Governments against massive migration.

We are proposing that the current legal rules on asylum and protection should be updated to 1) consider the constraints that a major inflow of migrants may in principle create to receiving states at least in some extreme cases and in order to 2) prevent and react to abuses. In addition, the EU (and eventually also the United Nations) should act in order for the home Governments of those migrants without a title to stay in the EU to promptly take these persons back. We believe that a reform of the existing rules could weaken the political and eventually also legal basis for taking individual actions like those of Hungary and Italy. This way, the existing EU and international rules would become more balanced and, hence, politically stronger. Furthermore, the justification of individual actions like those of the Hungarian and Italian authorities would be more difficult and, eventually, there would be less of a reason for such types of actions.

Future research may focus on the development of methodologies useful to determine whether a country is exposed to unmanageable inflows of migrants, taking into account factors like the number of arrivals, recipient states' managerial and financial resources, the crime rate, and the percentage of crimes committed by migrants. This is in order to assess the legitimacy of the eventual and probable future complaints coming from Governments presenting their country as overburdened.

\section{LITERATURE}

1. Ackleson, J.: Landscape of Immigration in Europe, International Studies Review, Vol. 7(4), 2005.

- DOI: 10.1111/j.1468-2486.2005.00547.x

2. Ambrosini, M.: Irregular Immigration in Southern Europe: Actors, Dynamics and Governance, Springer International Publishing AG, Vol. 17 (3), 2018.

- DOI: 10.33182/ml.v17i3.983

3. Anastasìa, S.; Anselmi, M.: Populist Punitiveness in the Italian Populistic Yellow Green Government, Partecipazione e Conflitto. Vol. 13(3), 2020.

- DOI:10.1285/i20356609v13i3p1469

4. Armstrong, A. B.: You Shall Not Pass! How the Dublin System Fueled Fortress Europe, Chicago Journal of International Law, Vol. 20(2), 2020.

5. Bhimji, F.: Contesting the Dublin Regulation: Refugees' and Migrants' Claims to Personhood and Rights in Germany. Intersections, Vol. 2(4), 2016.

- DOI:10.17356/ieejsp.v2i4.214 
6. Berti, C.: Right-wing populism and the criminalization of sea- rescue NGOs: the 'Sea-Watch 3' case in Italy, and Matteo Salvini's communication on Facebook, Media, Culture \& Society, Vol. 43(3), 2021.

- DOI:10.1177/0163443720957564

7. Bhimji, F.: Contesting the Dublin Regulation: Refugees' and Migrants' Claims to Personhood and Rights in Germany. Intersections, Vol. 2(4), 2016.

- DOI:10.17356/ieejsp.v2i4.214

8. Bocskor, A.: Anti-Immigration Discourses in Hungary during the 'Crisis' Year: The Orbán Government's 'National Consultation' Campaign of 2015. Sociology: the Journal of the British Sociological Association, Vol. 52(3), 2018 - DOI:10.1177/0038038518762081

9. Bove, V., Elia, L., \& Ferraresi, M. (2019). Immigration, fear, and public spending on security I VOX, CEPR Policy Portal. https://voxeu.org/article/immigration-fear-and-public-spending-security as accessed on the 1st June 2021

- DOI: https://doi.org/10.1093/jleo/ewab021

10. Bugge, M.: Obedience and Dehumanization: Placing the Dublin Regulation within a Historical Context, Journal of Human Rights and Social Work, Vol. 4(1), 2019.

- DOI:10.1007/s41134-019-0090-y

11. Cafiero, C.: The Dublin Regulation: Critiques and Latest Attempts to Reform, Union of Jurists of Romania, Law Review, Vol. IX(1), 2019.

12. Campbell, B.: Caradura: Migration, Informal Labor, and the Problem of Enacting Trust in a Spanish Enclave in Morocco, Political and Legal Anthropology Review, Vol. 41(1), 2018.

- DOI:10.1111/plar.12246

13. Carboni, G.: European Virtual Politics: Capitalizing on Immigration, Politeja, Iss. 63, 2019.

- DOI:10.12797/Politeja.16.2019.63.10

14. Castaldo, A.; Verzichelli, L.: Technocratic Populism in Italy after Berlusconi: The Trendsetter and his Disciples, Politics and Governance, Vol. 8 (4), 2020.

- DOI:10.17645/pag.v8i4.3348

15. Cervi, L.; Tejedor, S.: Framing "The Gypsy Problem": Populist Electoral Use of Romaphobia in Italy (2014-2019), Social Sciences, Vol. 9(6), 2020.

- DOI:10.3390/socsci9060105

16. Davidov, E.; Meulemann, B. ; Schwartz, S. H; Schmidt, P.: Individual values, cultural embeddedness, and anti-immigration sentiments: Explaining differences in the effect of values on attitudes toward immigration across Europe, Kölner Zeitschrift für Soziologie und Sozialpsychologie, suppl. Supplement, Vol. 66, Sep 2014.

- DOI:10.1007/s11577-014-0274-5 
17. Dunn, G.: Destination Europe: The Persistence of Immigration to Europe, International Review, Vol. 36(3), 2015.

18. Etzioni, A.: Immigration: Europe's Normative Challenge, Journal of International Migration and Integration, Vol. 20(1), 2019.

- DOI:10.1007/s12134-018-0593-x

19. Evolvi, G.: Politics, Islamophobic Tweet. The Hashtags \#Brexit and \#chiudiamoiporti, Partecipazione e Conflitto, Vol. 12(3), 2019.

- DOI:10.1285/i20356609v12i3p871

20. Fuller, L. L.: The Morality of Law (rev. edn)., Yale University Press, 1969.

21. Gataullina, I. A.; Shmelev, D. V.; Kozlova, O.; Gilmutdinova, O.; Shagbanova, I. B.; et al: The "New National Problem" in Europe: Problems of Migration Policy at the End of the 20th Century, European Research Studies, Vol. 20(4B), 2017, pp. 666.

22. La Rocca, G.; Di Maria, R. and Frezza, G.: Media, Migrants and Human Rights. in the Evolution of the European Scenario of Refugees' and Asylum Seekers' Instances, 2020, Kindle Edition

- DOI: https://doi.org/10.3726/b17162

23. Gontijo, L. C B; Lana, A. D. S.: Fear of the Other within the Contemporary 'Migration Crisis': Arab-Muslim Migration towards Europe and the Condition of Otherness Journal of Identity and Migration Studies, Vol. 14(2), 2020.

24. Guiraudon, V.: The 2015 refugee crisis was not a turning point: explaining policy inertia in EU border control. European Political Science, Vol. 17(1), 2018.

- DOI:10.1057/s41304-017-0123-X

25. Hansen, Art (ed.): Involuntary Migration and Resettlement: The Problems and Responses of Dislocated People, Taylor \& Francis Group, 2020.

- DOI: https://doi.org/10.4324/9780429052293

26. Iocco, G.; Lo Cascio, M.; Perrotta, D. C.: Sociologia Ruralis: 'Close the Ports to African Migrants and Asian Rice!': The Politics of Agriculture and Migration and the Rise of a 'New' Right-Wing Populism in Italy, Oxford Vol. 60 (4), 2020.

- DOI:10.1111/soru.12304

27. Jones W., Teteytelboym, A, and Rohac, D. Europe's Refugee Crisis: PRESSURE POINTS AND SOLUTIONS, American Enterprise Institute, 2007, https://www. aei.org/research-products/report/europes-refugee-crisis-pressure-points-andsolutions/ as accessed on the 25th September 2021

28. Kessedjian, C.: Public Order in European Law, The Erasmus Law Review, Vol. 1(1), 2007.

29. Koopmans, R.; Lancee, B.; and Schaeffer, M.: Social Cohesion and Immigration in Europe and North America: Mechanisms, Conditions, and Causality, Taylor \& Francis Group, 2014.

- DOI: https://doi.org/10.4324/9781315775975 
30. Körösényi, A.; Illés, G., and Gyulai, A. G.: The Orbán Regime: Plebiscitary Leader Democracy in the Making, Taylor \&amp; Francis Group, vol 7 (1), 2020.

- DOI: https://doi.org/10.4324/9780429053436-1

31. Papuc, P.C.: Parallel Between the Refugee Concept according to the Convention relating to the status of Refugees from 1951 and to its Protocol from 1967 and the Refugee Concept according to European Law, Challenges of the Knowledge Society, 2018, vol. 12.

32. Podda, P.A. The Legality of Migrant Quotas and the Pronouncement of the Court of Justice of the European Union on Migrant Quotas after the Action for Annulment of Slovakia and Hungary. Does a EU Member State Have its Own Obligations to Respect EU Law and also the Right to Defend Public Order and Financial Stability, Per Curiam, Journal of the of the School of Law of the Anglo American University, Prague, vol. 9, 2021.

33. Rydliński, B.M.: Viktor Orbán - First Among Illiberals? Hungarian and Polish Steps Towards Populist Democracy, On - line Journal Modelling the New Europe, Iss. 26, 2018.

- DOI: 10.24193/OJMNE.2018.26.07

34. Schultz, J.: The Internal Protection Alternative in Refugee Law: Treaty Basis and Scope of Application under the 1951 Convention Relating to the Status of Refugees and Its 1967 Protocol, 2019.

- DOI: https://doi.org/10.1163/9789004361966

35. Solarz1, A. M.: Poland The Impact of Immigration Crisis On Europe's Cultural Condition: Why Are the Poles 'Apprehensive' About Muslims?, University of Warsaw, 2020.

36. Trauner, F.; Turton, J.: Welcome culture: the emergence and transformation of a public debate on migration, Österreichische Zeitschrift für Politikwissenschaft, Iss. 1, 2017.

- DOI:10.15203/ozp.1587.vol46iss

37. Trines. S.: Lessons from Germany's Refugee Crisis: Integration. Costs. and Benefits. WENR, 2017. https://wenr.wes.org/2017/05/lessons-germanys-refugee-crisis-integration-costs-benefits

38. Üstün, E. Y.: The Internal Protection Alternative in Refugee Law: Treaty Basis and Scope of Application under the 1951 Convention Relating to the Status of Refugees and Its 1967 Protocol, Insight Turkey, Vol. 22(2), 2020.

39. de Voss, V.: The 2015 Refugee Crisis, Sister Namibia, Vol. 27(3), 2015.

40. Webster, E.: Dignity, Degrading Treatment and Torture in Human Rights Law: The Ends of Article 3 of the European Convention on Human Rights, New York, 2018.

- DOI: https://doi.org/10.4324/9781315719443 
41. Yilmaz, F.: Right-wing hegemony and immigration: How the populist far-right achieved hegemony through the immigration debate in Europe, Current Sociology, Vol. 60(3), 2012.

- DOI: $10.1177 / 0011392111426192$

42. Zapalacova, V: The capability of a Member State to protect its national security by placing a limit on mass irregular migration, Master Thesis, 2021, Anglo American University

\section{ONLINE SOURCES:}

1. [https://migrationdataportal.org/regional-data-overview/europe\#past-and-present-trends=] accessed on 1/7/2021

2. [https://www.ohchr.org/Documents/Issues/MHR/ReportLargeMovements/ FIDH2\%20.pdf], accessed on 1/7/2021

3. [http://www.bgcentar.org.rs/bgcentar/eng-lat/wp-content/uploads/2021/03/Human-Rights-in-Serbia-2020-za-web.pdf], accessed on 1/7/2021

4. [https://europeanlawblog.eu/2020/04/14/coming-to-terms-with-the-refugee-relocation-mechanism/], accessed on 1/7/2021 